\title{
LEAN MANUFACTURING vs COVID-19
}

\section{Zoran Cekerevac}

University MB, Faculty of Business and Law, Belgrade, Serbia https://orcid.org/0000-0003-2972-2472

\section{Zdenek Dvorak}

University of Zilina, Faculty of Security Engineering, Zilina, Slovak Republic https://orcid.org/0000-0002-8320-1419

\section{Lyudmila Prigoda}

Maikop State Technological University, Faculty of Finance and Economics, Maykop, Russia

https://orcid.org/0000-0002-4762-3892

\section{OMESTE}

JEL Category: M11

\begin{abstract}
During the COVID-19 pandemic, companies coped and still must deal with uncertainty greater than ever. Due to the unpredictability of consumer demand, the incredible growth in demand for certain products, dramatic fluctuations in supply chains, and general economic instability, the future still looks uncertain. It is up to the manufacturers to determine how things will be sorted out in the new normality, i.e., which changes will be long-lasting or even permanent. Lean production has emerged in recent decades as an excellent solution to increase the economy and quality of production and meet customer needs. In the market conditions affected by the COVID-19 pandemic, producers work in a significantly changed environment, and many wonder whether lean production remains as relevant and valuable as in the past. The paper discusses lean production from different aspects as the essence of the principles of the lean concept, events during the pandemic, and expectations in the post-Covid period. We used some examples to support the analysis of factors that negatively affect the course of lean production as well as some bright examples of companies that took advantage of lean production in the new conditions. The conclusions consider answer whether lean production will survive the consequences of the COVID-19 pandemic.
\end{abstract}

Keywords: Lean production, COVID-19, pandemic, digitalization, IoT

\section{INTRODUCTION}

There are different paths to success. But longterm success certainly requires leadership with a

Address of the corresponding author:

Zoran Cekerevac

表='zoran@cekerevac.eu vision, a clearly defined mission, a built system of values, specifically defined goals, and a strategy established according to the interest groups, as well as efficient resource management, human and material resources (Čekerevac, Davidović, \& Čekerevac, 2010). Changes in the business environment have a significant impact on the choice of the way the company works. Overnight 
they can affect the choice of optimal solutions. This paper will analyze the impact of the COVID19 pandemic on production quality management.

In times of increasingly complicated market conditions, as well as the need for adapting to the European norms in transitional countries, put managers of each company in a difficult situation (Davidovic \& Čekerevac, 2005a). In the complexity of the problem, which the mentioned package includes, the COVID-19 pandemic added a new challenge in managers' decisions. It is a delicate task, due to the lack of adequate knowhow and absence of previous educating and training.

The pandemic also brought big challenges in terms of transporting goods practically all over the world. Special problems have arisen in road traffic. In addition to energy supply problems, such as in the UK, also, there appeared a shortage of truck drivers. The reasons for the latter vary from country to country, from Brexit in the UK to the departure of qualified drivers from poorer countries to richer ones in search of higher earnings. In such situations, part of the problem can be solved by increasing the volume of transport by rail. But, in praxis, in the multimodal transport, there could appear some situations when, compared to the regular state, some limitations in the transport capacities in some sectors appear. The organization of the railway transport in this segment is crucial for the transport capacity of the whole route. The management methods, in this case, are very different from the usual methods. (Davidovic \& Čekerevac, 2005b)

Before analyzing the specific impact of the COVID-19 pandemic on the world market and lean production, we will point out some characteristics of the Lean concept. Automation is recommended for waste removal in production, and using the latest equipment is one of the best ways to do that. Pre-programmed machines can produce parts in narrow tolerances and thus help eliminate waste and finishing. High levels of automation maximize uptime and improve parts accuracy and consistency while reducing costs. Additional benefits of automated equipment that supports lean initiatives include (Curtis, 2021):

- Repeatability/accuracy - Increases the quality of parts and minimizes processing.
Quality - The quality of the parts does not depend on the operators' skills. When we talk about quality here, we mean that producer produced the product following the construction documentation.

- Pre-preparation of parts - The material and parts warehouse can deliver the next batch of materials or parts on time, reducing lost handling time.

- Automatic tools - They reduce adjustment costs and allow production continuity.

- Partially unmanned operations - allow that while machines are running, the operator can write programs or perform the process operations that require manual work.

A just-in-time (JIT) inventory management system can be used to efficiently manage inventory and reduce the cost of goods sold, as this strategy ensures that reproductive material arrives when needed in production processes. This costeffective inventory management strategy helps minimize or eliminate excess resources and allows for continuous inventory flow. A JIT strategy can be more effective if paired with the Kanban system - while JIT reduces inventory, Kanban signals when more material is needed. A company can calculate safety stock levels by combining customer expectations and delivery time requirements with its internal production capacity so the products can be ready when the customer needs them.

The JIT strategy, when properly implemented, can bring benefits to the company that applies it to its clients, such as (Curtis, 2021):

- Increased efficiency - Production lines can operate continuously because materials are available to meet production needs.

- Reduced waste.

- Reduced inventory costs.

Improved delivery to customers.

- Reduced bottlenecks and areas with increased defects.

Continuous improvement is at the core of the lean concept. The use of performance measurement standards helps the company monitor progress and shows how internal improvements help to improve results. All members of the team are thinking about how to achieve product perfection. 


\section{HOW LEAN HELPS COMPANIES ADAPT}

In recent decades, realizing that TQM provides small but continuous improvements, achieving drastic improvement in production and reducing inventories across companies, many companies have reengineered their business processes. As a systemic approach, reengineering generates strategic, technical-technological, economic, social, cultural, and other changes in the organization. Concepts of crucial importance in production and transport include:

- Just in time,

- Just in Sequence, and

- Make or buy?

In the first two concepts, the idea is to reduce the stock of parts to the planned minimum, and the second is an optimized version of the first one. The third concept is important for deciding what a company will produce or buy on the market. The assumption is that a specialized external manufacturer will be more efficient and achieve better quality at a lower price. So the company should only deal with what is more competitive than others.

The result of this approach is the realization of a lean production concept that would eliminate everything that does not add value for the customer (CGMA, 2021):

- Overproduction - Production ahead of demand.

- Defects - Reduction of costs of defect production.

- Waiting - Production interruptions and idling.

- Motion - Optimization of movement of workers.

- Inventory - Stocks of finished goods or work in progress not being processed.

- Transport - Excessive movement of materials, work in progress, or finished goods.

- Over-processing - Processing to compensate for poor design or production processes.

The concept can be applied to industries across many fields, but it is especially relevant to the manufacturing sector, among ISO 9001 certified organizations (AQM, 2021).

With an emphasis on increasing productivity and elimination of so-called waste, Lean production works on the edge and needs to consider the introduction of new technologies and the provision of personnel who can use them. In addition, lean requires manufacturers to work with as many resources as they need to succeed - and no more. That is why companies must take care of (Langstroth, 2021):

1. integrating digital technologies. That primarily refers to the use of Industry 4.0 digital technologies. In its annual Industry 4.0 survey, McKinsey (Agrawal, Dutta, Kelly, \& Millán, 2021) found that $94 \%$ of 400 global manufacturing companies reported that advanced production technologies had helped them keep their operations running during the crisis. A majority (56\%) considered digital technologies critical in their successful response to the crisis. That is primarily because, thanks to the advanced analytics applications, robotics, and software, they were able to make more sophisticated decisions. Using digital technologies, companies like Unilever, Micron, Tata Steel, Novo Nordisk, Alibaba, Saudi Aramco, and Hitachi achieved significant shifts in manufacturing productivity, 20-75\% (Langstroth, 2021).

2. resolving supply chain issues in real-time. In 2020 , there was a huge disruption in supply chains. Some manufacturers even created war rooms, where supply and demand planners devised alternative supply routes and alternative solutions. Operational weaknesses that forced some companies to transform have come to light. Some businesspeople consider lean to be an effective tool for solving problems in the supply chain because by applying the lean supply chain, partners benefit from the system of interconnection by balancing supply and demand. With the lean, manufacturers have the metrics they need to real-time monitor whether they met their goals and objectives. However, the problem arises when some goods are not in sufficient quantities. In such cases, the whole theory largely ceases to be valid. Even in such situations, digital technology is a significant player, as manufacturers can use it to automate the digital supply network (DSN), receive realtime reports, and can align production with available materials in an increasingly complex distribution network. 
3. preventing excess product. Protection against overproduction is especially relevant for the pandemic era. The goal is to produce products in quantities sufficient to meet actual demand, whether smaller or larger. It makes producers more sensitive and does not produce stocks they would have to store. It is one of the best ways to avoid excess product and all the inherent waste that goes with it. However, we can also discuss it based on the events during the pandemic. Due to the lockdown, the demand for certain goods fell sharply, which reduced the production of these goods. It was difficult to expect buyers would decide to buy new cars when everything was uncertain except that they could not leave their homes. However, immediately after the abolition of the lockdown and thanks to subsidies obtained by the state, appetites rose sharply, and production could not meet the needs. It should be borne in mind here that due to the (unexpected?) energy crisis, there have been major disruptions in the supply of energy and raw materials, so appeared significant shortages. For example, because of the lack of energy, China faced a huge reduction in zinc production. That consequently affected the shortage of aluminum in Europe, which can practically stop production lines in the European automotive industry. Manufacturers in the automotive industry of China and the United States are in a more favorable situation because these two countries have their production of zinc enough for their needs. Even worse is in terms of computer components. Before pandemics, car manufacturers have mostly met their needs with Chinese suppliers. At the pandemic, they must try to secure their production in Europe now. In this case, the question 'Make or buy?' from the beginning of Chapter 2 of this paper received a different answer from the one that would be valid under normal conditions. Also, many countries have introduced protection of their markets by restricting imports and/or exports. It has further influenced supply instability.

4. leveraging the power of partnerships. According to a Deloitte report for 2020 (Stefanita, Kawamura, \& Schroeck, 2020), the most successful manufacturers today achieve efficiency through powerful partnership strategies that allow them quickly develop and test new business models. By redesigning production operations and sales models, they can speed up production, adapt more flexibly to customer needs and reduce the time required to enter the market. In the 2019 Ease of Doing Business Report, Group 2112 (2020) reported that nearly three-quarters of partners complained about overly complicated affiliate programs and said they sought greater support, transparency, and predictability in the programs. Nearly $40 \%$ want clear engagement rules, improved training programs, and simplified incentive management. $61 \%$ of partners believe that there are not enough strategic guidelines, and they would like more transparent requirements of the Market Development Fund (MDF). $70 \%$ of partners believe that the inclusion processes have too many steps and could be simplified. Partnerships need to focus on mutual success, so it is crucial to align business goals, and one of the good ways is to develop a clearly defined joint business plan.

5. improving environmental sustainability. In addition to the fight against the pandemic, the fighting for the protection of Earth is becoming more pronounced. Environmentally sustainable production strategies, such as waste reduction, reuse, and improved energy efficiency, are becoming increasingly popular. They can add value, reduce costs, and shorten production times. In addition to becoming crucial in achieving compliance with an increasingly complex regulatory environment, these strategies are also popular among consumers who are increasingly opting for a particular manufacturer interested in environmental protection. Lean can help in this case as well. For example, the Lean concept, known as Operator Care, is used to design standards that reduce variations in the production process, which leads to less waste of products and raw materials. Ultimately, care for the environment is significantly affected by increasingly stringent legislation aimed at zero $\mathrm{CO} 2$ emissions. Implementing lean when choosing new equipment, upgrading existing equipment, or selecting manufacturing 
components, can help managers evaluate environmental impacts. For example, the Lean concept known as Operator Care is used to design standards of practice that reduce variations in the manufacturing process, leading to less waste of product and raw materials, reduced energy and water consumption, and cutting emissions while reducing costs.

6. streamlining and supporting the workforce. Lean also deals with problems on the workforce side, preventing the loss of resources in time and talent. Integrating Lean and modern technology can solve many labor productivity problems. For example, the 'smart factories' can analyze data collected from sensors in production facilities, focus on quality and performance issues, and perform predictive maintenance, minimizing equipment downtime. Through the digitalization of business, companies use proven tools to optimize production performance and reprogram business to achieve the necessary organizational changes and respond to the challenges of the post-pandemic era we are approaching. It is noteworthy that according to a survey conducted by SAP ${ }^{1}$ before the COVID-19 pandemic, $46 \%$ of decision-makers believed that digitalization provided the same opportunities for SMEs and large companies, and $37 \%$ believed that SMEs due to its flexibility in advantage over large companies. (Ćesarović, Bogavac, \& Čekerevac, 2021).

Although we can discuss when lean manufacturing originated, with certainty, we can say that its theoretical roots are represented by Frederick Winslow Taylor's 'Shop Management' (1911). Also, we can say that Shigeo Shingo and Taiichi Ohno, and Toyota Motor Corporation are most responsible for its practical application. But lean has neither been universally adopted nor developed continuously over the years. Reengineering of business processes on lean manufacturing principles started in the early 1990s.

1 Abbreviation for "Systems, applications, and products in data processing"
The most important achievements as reducing the failure rate to zero and delivery times by three quarters, shown in the beginning, cannot continue forever despite regular investments in state-ofthe-art machines. Despite the success of the justin-time and other lean practices, the Lean is limited when a broader strategy of cooperation between teams, agile decision-making, and staff development does not support it.

The development of digital technologies has encouraged manufacturers to rethink the benefits of lean manufacturing. Lean and digital make a powerful combination to provide ultra-efficiency, productivity, and performance. Data-driven systems make it possible to obtain quality reports that help save time, reduce errors, and take advantage of opportunities in the best way, far beyond human capabilities. The levels of adoption of digital technology vary despite the availability and benefits of digital technology. $26 \%$ of manufacturers say they are thinking about digitalization but do not yet know how to apply it, but as many as $27 \%$ told researchers not to think about it. (Pamment, 2020) That was a cause for concern before COVID-19 struck, but we will see how many will change their opinions as a result.

Even in industries characterized by innovation, such as the pharmaceutical industry, it is surprising to see how many companies use paperbased tables, boards, and systems, regardless of their shortcomings. They end up with rigid production plans that cannot easily accept change, with processes duplicated unnecessarily. Their resources are either stretched or underutilized. Dynamic scheduling, supported by APS software ${ }^{2}$, allows manufacturers to iron out these inefficiencies. With access to the same information in real-time, production teams work together to spot where machine downtime or potential bottlenecks can become constraints. Since the plan is visible to everyone, there is no need for handovers at the beginning of each shift. It saves many hours every day.

We need to be aware that digital transformation is not an independent project but a project that drives the Lean methodology in the modern world. Overall, such improvements allow manufacturers

2 Advanced planning and scheduling (APS) software 
to make continuous improvements (or Kaizen) that are an integral part of lean. As we have seen, the most dedicated proponent of lean will not get far if it does not increase its capabilities through APS software and other software such as MRP and $\mathrm{ERP}^{3}$.

\section{LEAN MANUFACTURING DURING THE COVID-19 PANDEMIC}

Lean manufacturing, built on the assumption that reducing waste, eliminating surpluses, and precise operations, is the key to market success in conditions of market stability when supply chains function perfectly. The COVID-19 pandemic has caused a global disruption due to a lack of demand, reduced mobility of people and goods, a series of lockdowns, and ultimately reduced production. After the cessation of lockdown and the easing of restrictive measures, there was a sharp increase in demand for goods and services, which shook the market and led to shortages of parts and final products. Many orders will be able to be realized only in a few months, and in some countries, dealers inform their customers that the goods are not in stock (e.g., Raspberry Pi 4 were not on sale on November $1^{\text {st }}$, 2021, in Slovenia, Croatia, and Austria) ${ }^{4}$.

It turned out that those companies that did not have significant reserves of parts and components had massive problems continuing production. The automotive and aviation industries and those engaged in computers and related production equipment got into big trouble. As the world emerges from the pandemic, companies will try to find ways to keep their lean practices. (Hyder, 2021).

While the COVID-19 pandemic has highly endangered some industries, it has created conditions for fast growth for others. It primarily refers to masks and protective medical equipment, which production has made an enormous leap. Besides the billions of masks needed to produce, there appeared an enormous need for vaccine bottles, packaging for their transportation, respirators, and even new

3 ERP - Enterprise Resource Planning; MRPMaterial Requirements Planning. The primary difference between ERP and MRP is that ERP systems help plan and automate back-office hospitals, ambulances, and the like. The exponential growth of demand for certain products has enabled some companies to achieve extraordinary results by changing the production program. For example, the Pioneer company before coronavirus specialized in horse-drawn farm equipment, in just two weeks, created a prototype hospital bed, established a relationship with relevant partners, changed the production program, and managed to produce 50 beds in the first day. Now the Pioneer makes two hospital beds per minute. (AQM, 2021) they have managed to maintain lean manufacturing and prove that different goals can be achieved relying on the existing network of production capacities.

As the world changed in a pandemic, the manufacturing sector adapted to the new reality. The main changes are visible in (AQM, 2021):

- Ensuring the safety of workers. If remote work was not possible, the distancing of workers was applied to prevent the transmission of the virus.

- Visual displays and handwashing. Companies used transparent barriers to separate workers from others (clients or colleagues) where justified. Hand sanitizers have become standard equipment in stores, offices, and individual workplaces.

- Communication. Although some workers have worked from their homes and remote locations, good mutual communication, horizontal and vertical, continues to be important.

The management tried to be as efficient as possible. Team leaders focused on the most valuable tasks, neglecting the unimportant, and company leaders tried to adapt to the needs of consumers and streamline the products and highly demanded services. It is crucial, within lean manufacturing, to monitor the market daily and predict future conditions. Consequently, it is necessary to monitor the prices of raw materials on the market and decide what, how much, and when to buy to ensure uninterrupted production.

business functions, whereas MRP systems focus on materials management.

${ }^{4}$ (n.d., Raspberry Pi 4, 2021) 
COVID-19 has drastically changed the regularity of demand - with daily changes in forecasts, sudden inflows, and cancellations of orders which has highlighted the need for manufacturers to be flexible. Well, even though 2020 was not the year most companies had hoped for, it allowed manufacturers to take advantage of lean manufacturing to respond to shortages and problems caused by the pandemic. Lean manufacturing encompasses many different aspects, and the pandemic has given manufacturers who embrace lean manufacturing the opportunity to analyze weaknesses and address them directly.

2020 showed manufacturers more than ever before that lean production is flexible. The flexibility of the machines reflected in their ability to quickly adapt to the production of a new product and new production plan and volume, together with employees training, allow the company to react adequately when necessary. (Curtis, 2021)

Industries are not immune to extreme changes in the environment in which they operate. Such challenges push them towards accelerated digitalization. (Allgood, 2020) Companies quickly realized that the faster they move to automation and an environment that provides real-time information, the better the transformative effect will be in their business. For too long, leaders have seen automation as a replacement for workers. Bringing the $4^{\text {th }}$ Industrial Revolution to factories improved the quality of the workforce. Automating everyday tasks and increasing efficiency have freed workers to advance in new roles and responsibilities. If policymakers and businesses get it right, linking the physical and digital worlds could generate $\$ 3.9$ to $\$ 11.1$ trillion a year in economic value by 2025. (Manyika, et al., 2015) The pandemic is accelerating digital adoption due to working in an uncertain environment and the need for rapid turnaround.

The most pressures are in the areas of meat production and food transport. The pandemic is limiting the capacity of factories, supply chains are overloaded, and there are increasing demands to monitor food shipments to reduce loss and spoilage in transit. $5 \mathrm{G}$ technology can solve these challenges, enabling real-time monitoring and quick adjustment to temperatures, traffic patterns, and other factors. Even before the pandemic, classic industries like maritime shipping began to examine how to transform their business digitally, and it became imperative now.

COVID-19 pandemic creates greater demand for automation and contactless operations, with less human involvement, to limit exposure and control epidemics. 5G and IoT technologies enable the transformation of factories themselves. In Denmark, for example, there have been no closures of meat processing plants as we have seen in the United States. It is partly because one of the largest factories in the country is almost fully automated. (Allgood, 2020) 5G and IoT technologies will help bring that automation type to life in all industries.

During the pandemic, there was a significant increase in food delivery. Guests visited restaurants less and less due to lockdown and fear. Direct delivery to customers is becoming an increasingly common practice. Cellular connectivity becomes critical for monitoring and efficiently maintaining operations. With disrupted production and growing demand, many companies have begun to think about efficiency and spoilage of goods. A study conducted by the US National Institutes of Health showed farmers lose $60 \%$ of harvested cereal grains during the storage process. Ericsson has partnered with IntraGrain Technologies Inc. to provide a solution that allows farmers to digitally monitor grain storage conditions in silos, reducing spoilage and ensuring more products reach customers. (Allgood, 2020) In solving all the mentioned problems, 5G technology combined with loT can help.

There is an increasing transition from wired to wireless cellular connections in factories. It is primarily due to the possibility of easy reconfiguration of the network, machines, and processes when a responsible change in demand. Also, 3D printing increases due to delays in the supply chain - the innovation was born out of necessity and could have a long-lasting impact.

Private cellular networks offer other benefits, such as increased data security and device integrity, consistent high speeds, and seamless transitions between indoor and outdoor environments.

Stock problems arose during the pandemic. As is often the case, many blamed lean manufacturing 
and its basic principles. In the United States, due to the exceptional demand, most shelves with paper towels and toilet paper were left empty in the early phase of the pandemic. Also, the laptop supply went into problems. Many have started working from their homes, which they did not do before. In addition, online learning has become the standard for both pupils and students. Similar situations have occurred before. For example, in 2010, many blamed lean productions for component shortages faced by Apple and Nissan, among others, and quality problems at Toyota. (Jusko, 2020) Although, at that time, Apple was not considered a lean manufacturer. In defense of the lean principle, we must remark that Lean is not one-dimensional and does not mean only a minimum of inventory. It is a much broader notion that lean "changes the focus of management from optimizing separate technologies, assets, and vertical departments to optimizing the flow of products and services through entire value streams". (Jusko, 2020)

During the COVID-19 pandemic, lean again (quite unjustifiably) came out in a bad light. In its defense, we can object that there are practically no manufacturers who will keep so many reserves in warehouses that will meet their needs in a situation that will happen once a century, or maybe not even happen. Such reserves will more likely remain unused and be a loss.

Manufacturers who fully accept lean will see the pandemic as it is - a catalyst for change (Jusko, 2020). COVID-19 highlighted areas where production was not successful. The lean companies will attack these weaknesses and be better in future crises.

\section{LEAN MANUFACTURING IN A POST-COVID WORLD}

The impact of the global Covid-19 pandemic has called into question many lean practices in manufacturing companies. But one should always keep in mind that in lean production, the goal is to deliver value to customers, even when it comes to trouble. By using real-time data-based reports, manufacturers can continue to operate successfully in the future and maintain their costcutting initiatives.

While well-established supply chains, just-in-time inventory management, and minimal waste functioning as they should when the businesses a company depends on can meet demand, what happens when a global pandemic occurs?

Production breaks, part-time work, and global supply shortages have been a reality in the last twenty months. So, the question arises: Is there still a place for lean production in the world after Covid?

As the answer, we shall explain why lean production will continue and how producers can use it when the pandemic is over.

First and foremost, the finger is usually pointed at the lean whenever a rare occurrence shakes the production chain. The current Covid-19 pandemic is a painful but rare occurrence! (n.d., Lean manufacturing in a post-Covid world, 2021) The last similar occurrence, but of far smaller dimensions, was in 2006 with H5N1 (outbreak of bird flu). At the time, people were rapidly questioning lean production, especially JIT inventory management. But as the father of the lean behavior movement, Jim Womack, clairvoyantly wrote at the time (Womack, 2006): "The real problem is the lack of capacity to assemble the parts quickly into finished units. And thinking that companies on their own will maintain a buffer stock of finished units adequate for a true emergency is equally naïve. They would go bankrupt if they tried." Womack suggested that the governments' task should be maintaining stocks at the required level for emergencies to mitigate the effects of such a global event. This proposal is very problematic from the aspect of liberal capitalism. It is more suitable for some other social systems. But, knowing what happened during the COVID-19 pandemic, it does not seem such a ridiculous proposition. Let us not forget that lean production is not just about reducing costs, minimizing waste, and improving efficiency. The number one trigger for lean should always be to increase the value delivered to the customer.

Even when the manufacturer has the best supply chain and the leanest JIT inventory management, all this is in vain when the customer's order is not fulfilled on time or per their expectations.

Eventually, the Covid-19 pandemic will end. With mass vaccination and new drugs, the world will overcome the pandemic. Since they have not been able to travel freely for a long time, people 
will want to do so as soon as they can. Also, after lifting the blockades, we return to some semblance of normalcy. There is to expect that we will witness an increase in demand. We saw it during the occasional easing of restrictions. Manufacturers and service providers who will be able to respond to new market demands will emerge as winners.

One of the ways manufacturers can strike the right balance between inventory management and continuous customer enthusiasm is to take advantage of real-time data insight. Data and connectivity now play a vital role in increasing the efficiency of production lines. By using modern software systems, such as ERP and MRP solutions, manufacturers no longer need to rely on the best guesses. Instead, they can take advantage of the latest real-time information from their stores and beyond to see precisely where they are and their supply chain at any given time.

Such an adjustment allows manufacturers to a better plan. Also, they can react more quickly to changing dynamics and moods in the industry, including sudden increases in demand.

The global Covid-19 pandemic will force many manufacturers to reconsider their lean practices and, also, to analyze whether they will be sustainable after such a shocking event. Thanking a proactive approach to data exploitation some of them will be completely prepared to move forward.

If a Covid-19 pandemic in a company has called into question their lean manufacturing practices, then it is most often the case that the company was not lean before the pandemic.

The COVID-19 pandemic has caused shocks in the manufacturing sector. Some companies have wondered when the demand for their products will increase again. Many factories were closed with workers laid off. But there was also positive news. Many foods and toilet paper manufacturers have increased production to respond to panicky purchases. Some others have made good use of their skills and abilities by making hand gels, face shields, and fans. Of course, the successes of some pharmaceutical companies are immeasurable, as they have invested all their own (but, in addition, state's) resources in the development of vaccines and drugs against COVID-19.
Manufacturers are now adapting to the new conditions after coming out of the blockade. They will need to revise the demand forecasts. Also, they need set contingency plans for another sudden influx or drop in orders. New work practices must be adopted, including strict respect for employee distance and hygiene.

Those who already were hampered by inefficiency and low productivity caused by archaic processes and poor use of resources will suffer the most difficulties. However, at the same time, this is an opportunity for all companies to review their strategies and make improvements to achieve better performance and ensure their long-term survival.

COVID-19 emphasized the importance of innovation and resilience in the supply chain. It is time to rethink long-standing strategies and processes. Companies need to learn lessons from the crisis to build on success.

\section{CONCLUSIONS}

The crisis caused by the COVID-19 pandemic has highlighted the continuing lack of understanding of what lean is.

Coronavirus has brought many challenges to lean manufacturing and manufacturers in general. Those better prepared have managed to adapt to the new conditions and even derive significant benefits from it and ensure growth. Successful companies, capable of quickly adapting to different business conditions, could reduce production after a pandemic and return to the prepandemic range and volume without big shocks. Companies that have adopted the lean concept in its broadest form have more easily overcome the onset of the crisis and coped better in a pandemic. Those who did not work following the lean concept encountered big business problems. The problem level depends on their size, product range, and readiness for rapid transformation.

Lean production has proven problematic in some cases, primarily due to the lack of reproductive material. But the truth is that very few are companies have sufficient reserves for a longterm crisis as the COVID-19 pandemic is. The pandemic is a big test that shows how companies, industries, and even states organized and prepared themselves to work in the crisis. 
Based on numerous research, including this one, it is to get an impression that the proponents of lean production look to the future of this concept with a lot of faith. To the question 'Can lean production survive in the turbulent conditions of a pandemic?', they will answer with 'Yes, from its origins, lean evolved to offer companies the ideal set of tools to navigate within this new environment.' However, if we analyze the current situation on the market of goods and services, many will answer with: 'Yes, but...'

\section{WORKS CITED}

2012 Group. (2020, 03 13). 2019 ease of doing business report. In J. D. Fisher, Elevating the human experience for partners. CMO Today. Retrieved from 2112 Group.

Agrawal, M., Dutta, S., Kelly, R., \& Millán, I. (2021, 01 15). COVID-19: An inflection point for Industry 4.0. Retrieved from McKinsey \& Company: https://www.mckinsey.com/businessfunctions/operations/our-insights/covid-19-an-inflection-point-for-industry-40

Allgood, K. (2020, 12 01). COVID-19 is accelerating the digitalization of industry. Retrieved from ericsson.com: https://www.ericsson.com/en/blog/2020/12/covid19-industry-digitalization

AQM. (2021, 06 29). Lean Manufacturing in the Age of COVID-19. Retrieved from American Quality Management: https://aqmauditing.com/lean-manufacturing-in-the-age-of-covid-19/

CGMA. (2021). Lean production - What is it? Retrieved from CGMA: https://www.cgma.org/resources/tools/cost-transformation-model/lean-production.html

Curtis, K. (2021, 02 03). Lean Manufacturing in the Midst of COVID-19. Retrieved from Estes: https://www.estesdm.com/lean-manufacturing-in-the-midst-of-covid-19/

Čekerevac, Z., Davidović, B., \& Čekerevac, P. (2010). Total quality management in public administration - the case of municipal government,. Zborník prispevkov z medzinarodnej vedeckej konferencie Ekonomicky a socialny rozvoj Slovenska (pp. 113-125). Bratislava, SK: VŠEMVS. Retrieved from https://www.cekerevac.eu/biblioteka/K34.pdf

Ćesarović, A., Bogavac, M., \& Čekerevac, Z. (2021). THE IMPACT OF THE PANDEMIC ON THE ECOMMERCE OF SMALL AND MEDIUM ENTERPRISES. Proceedings of the 76th International Scientific Conference on Economic and Social Development. Belgrade: ESD.

Davidovic, B., \& Čekerevac, Z. (2005a). The choice of strategy for introducing quality management into logistics. Proceedings of 8th International Scientific conference LogVD 2005. Žilina, Slovakia: FSI. Retrieved from https://www.cekerevac.eu/biblioteka/K07.pdf

Davidovic, B., \& Čekerevac, Z. (2005b). Integration of the System for Providing Quality and Controlling Into Logistic Processes. Proceedings of Fifteenth International Scientific Conference Transport 2005. Sofia, Bulgaria: VTU.

Hyder, S. (2021, 02 22). How Covid-19 Has Changed Lean Manufacturing Practices: A Case Study With iBASEt. Retrieved from Forbes: https://www.forbes.com/sites/shamahyder/2021/02/22/howcovid-19-has-changed-lean-manufacturing-practices-a-case-study-withibaset/?sh $=6 f 87 \mathrm{c} 7 \mathrm{c} 57 \mathrm{e} 80$

Jusko, J. (2020, 10 29). COVID-19 Puts Lean in the Crosshairs of Controversy. Retrieved from IndustryWeek: https://www.industryweek.com/operations/continuousimprovement/article/21145065/covid19-puts-lean-in-the-crosshairs-of-controversy

Langstroth, D. (2021, 03 18). Is Lean Manufacturing Still Relevant in 2021 and Beyond? . Retrieved from Four Principles An Abdul Latif Jameel Company: https://fourprinciples.com/expertopinion/is-lean-manufacturing-still-relevant-in-2021-and-beyond/

Manyika, J., Chui, M., Bisson, P., Woetzel, J., Dobbs, R., Bughin, J., \& Aharon, D. (2015, 06 01). Unlocking the Potential of the Internet of Things. Retrieved from McKinsey Digital: 
https://www.mckinsey.com/business-functions/mckinsey-digital/our-insights/the-internet-ofthings-the-value-of-digitizing-the-physical-world

n.d. (2021, 05 20). Lean manufacturing in a post-Covid world. Preuzeto sa The Manufacturer: https://www.themanufacturer.com/articles/lean-manufacturing-post-covid-world/

n.d. (2021, 11 1). Raspberry Pi 4. Retrieved from Raspberry Pi: https://www.raspberrypi.com/products/raspberry-pi-4-model-b/?variant=raspberry-pi-4-model$\mathrm{b}-8 \mathrm{gb}$

Pamment, L. (2020, 05). The importance of lean manufacturing in the post-covid-19 world. Retrieved from IT In The Supply Chain: https://itsupplychain.com/the-importance-of-lean-manufacturingin-the-post-covid-19-world/

Stefanita, C., Kawamura, J., \& Schroeck, M. (2020, 10 23). Redesigning partner experience in Industry 4.0. Retrieved from Deloitte Insights: https://www2.deloitte.com/us/en/insights/focus/industry-40/partner-ecosystem-customer-experience-outcomes.html

Taylor, F. W. (1911). Shop Management. McGraw-Hill.

Womack, J. (2006, 01 22). Just in Time, Just in Case, and Just Plain Wrong. Retrieved from Lean Enterprise Institute: https://www.lean.org/the-lean-post/articles/just-in-time-just-in-case-andjust-plain-wrong/

Received for publication: $\quad$ 03.11.2021

Revision received: $\quad 17.12 .2021$

Accepted for publication: $\quad 06.01 .2022$

\section{How to cite this article?}

Style - APA Sixth Edition:

Cekerevac, Z., Dvorak, Z., \& Prigoda, L. (2022, 01 15). Lean manufacturing vs COVID-19. (Z. Cekerevac, Ed.) MEST Journal, 10(1), 1-11. doi:10.12709/mest.10.10.01.01

Style - Chicago Sixteenth Edition:

Cekerevac, Zoran, Zdenek Dvorak, and Lyudmila Prigoda. 2022. "Lean manufacturing vs COVID-19." Edited by Zoran Cekerevac. MEST Journal (MESTE) 10 (1): 1-11. doi:10.12709/mest.10.10.01.01.

Style - GOST Name Sort:

Cekerevac Zoran, Dvorak Zdenek and Prigoda Lyudmila Lean manufacturing vs COVID-19 [Journal] // MEST Journal / ed. Cekerevac Zoran. - Belgrade - Toronto : MESTE, 01 15, 2022. - 1 : Vol. 10. - pp. 1-11.

Style - Harvard Anglia:

Cekerevac, Z., Dvorak, Z. \& Prigoda, L., 2022. Lean manufacturing vs COVID-19. MEST Journal, 15 01, 10(1), pp. 1-11.

Style - ISO 690 Numerical Reference:

Lean manufacturing vs COVID-19. Cekerevac, Zoran, Dvorak, Zdenek and Prigoda, Lyudmila. [ed.]

Zoran Cekerevac. 1, Belgrade - Toronto : MESTE, 01 15, 2022, MEST Journal, Vol. 10, pp. 1-11. 